\title{
Economic Feasibility Analysis of Highway Project using Highway Development and Management (HDM-4) Model
}

\author{
Pratiksha. R. Patil \\ Dept. of Civil-Construction Management Engineering \\ Rajarambapu Institute of Technology, \\ Maharashtra, India
}

\author{
Prof. Dhananjay. S. Patil \\ Dept. of Civil-Construction Management Engineering \\ Rajarambapu Institute of Technology, \\ Maharashtra, India
}

\begin{abstract}
A well-developed transportation system plays vital role in economic development of the country. The huge increase in vehicular population creates traffic congestions on city roads. Thus, to reduce traffic bottleneck, creation of new road infrastructure as well as improvement of existing one has long term economic and social benefits. The economic benefits are calibrated on the basis of Economic Internal Rate of Returns (EIRR). The Mumbai and Pune are the major cities of Maharashtra state, due to economic and industrial development in those cities faces frequent and heavy traffic jam on highway connecting to both cities. The scope of present study consists of evaluating the impact on traffic and checking economic viability of the project. Strengthening and widening for six lanes flexible pavement which named as, Mumbai Pune section of NH-4. The HDM-4 is software used for checking the engineering and economic viability of the investment in this road project. It was observed that results obtained with improvement alternatives are economic viable.
\end{abstract}

Keywords - Traffic congestions; Economic Internal Rate of Returns (EIRR); HDM-4 software; Economic viability; Social benefits.

\section{INTRODUCTION}

Highways are the dominant mode of transportation in India. Due to improvement in transportation network, reduction in transportation costs can be realized in numerous ways, such as reduction in travel time, decrease in vehicle operating costs, increased safety and reduction in the level of environmental pollution. Improvement of highway network bring economic benefits in long-term by raising the productivity, innovation, lower prices, increases the income and overall creates more jobs thus bring more boom to the economy.

The decision-making process for development of best suitable infrastructure strategy for highway section suffers from lack of customized economic evaluation tools. The Word Bank's Highway Development and Management Tool (HDM-4), developed by the International Study of Highway Development and Management (ISOHDM) funded by World Bank, presents a good frame work for economic evaluation of road investments on improvements.

\section{OVERVIEW OF HDM-4}

HDM-4 is a computer software for Highway Development and Maintenance Management System. It is a decision-making tool for checking the Engineering and Economic viability of the investments in road projects. The World Bank for the global use has developed it. Following are the three main areas of analysis in HDM-4 which can be undertaken using the following applications: Project analysis, Programme analysis and Strategy analysis:

World Bank for the global use has developed it. Following are the three main areas of analysis in HDM-4 which can be undertaken using the following applications: Project analysis, Programme analysis and Strategy analysis:

- Project analysis: Project analysis allows the users to assess the physical, functional and economic feasibility of specified project alternatives by comparison against a base case (do nothing). The project analysis can be done for maintenance of existing roads, improvement of existing roads, new construction, Stage construction, Project evaluation.

- Program Analysis: Multi-year rolling program for road network through maximization of NPV/Cost ratio. It deals primarily with the prioritisation of a defined long list of candidate road projects into a one-year or multiyear work programme under a defined budget constraint.

- Strategic Analysis: Analysis of whole network for long term planning under different budget scenarios.

\section{STUDY AREA}

\section{General}

Mumbai and Pune cities situated at western part of Maharashtra and is a section of NH-4 as shown in "Fig. 1", having total length of 111 Kilometre. The project road lies between $18^{\circ} 55^{\prime}$ longitude and $72^{\circ} 54^{\prime}$ latitude. 


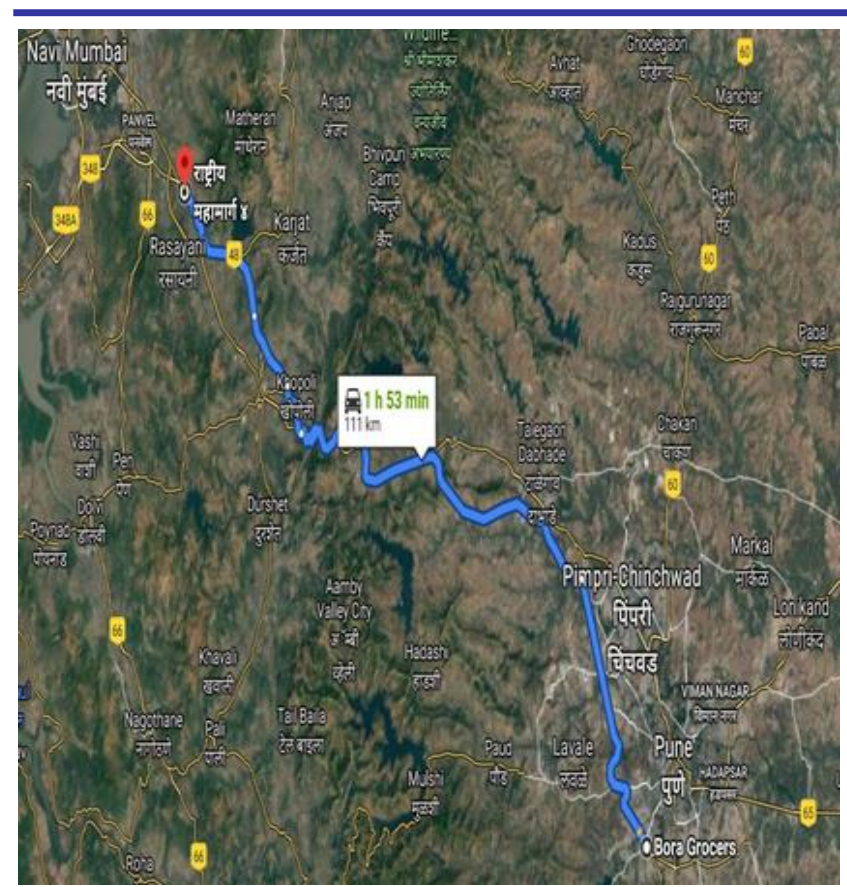

Fig. 1. Google Image of Study Area

\section{Climate}

Climatic condition parameters are represented in Table I.

TABLE I CLIMATE PARAMETER VALUES
\begin{tabular}{|l|c|}
\hline \multicolumn{1}{|c|}{ Parameters } & Value \\
\hline Temperature range & $20.7-35.8$ \\
\hline Moisture Classification & Arid \\
\hline Yearly Precipitations & $1445 \mathrm{~mm}$ \\
\hline Typical Moisture Index: & $62-70$ \\
\hline
\end{tabular}

\section{INPUT DATA}

The input data for HDM-4 Model consists of various parameters which are classified as below,

\section{Road Network Data}

The road network data included road Inventory data, road geometric details, structural evaluation, pavement condition and evaluation of pavement material as given in Table II.

\begin{tabular}{|c|c|}
\hline Pavement Type & $\begin{array}{l}\text { Asphalt Mix on Stabilised Base } \\
\text { (AMSB) }\end{array}$ \\
\hline Surface class & Bituminous \\
\hline Length $(\mathrm{km})$ & 111 \\
\hline Carriageway Width $(\mathrm{m})$ & 24 \\
\hline MT AADT & 44940 \\
\hline Rise Fall (m/km) & 30 \\
\hline $\begin{array}{l}\text { Avg.horizontal curvature } \\
(\mathrm{deg} / \mathrm{km})\end{array}$ & 15 \\
\hline
\end{tabular}

\section{Vehicle Fleet Data}

The vehicle fleet data included the collection of traffic volume count \& growth factors, basic vehicle characteristics and economic cost details of vehicles and as shown in Table III, IV and V respectively.

TABLE III TRAFFIC VOLUME COUNT \& ANNUAL GROWTH RATE
\begin{tabular}{|c|c|c|}
\hline Vehicle Type & Traffic Composition (\%) & $\begin{array}{c}\text { Annual } \\
\text { Growth }(\%)\end{array}$ \\
\hline Two-Wheeler & 1.22 & 2 \\
\hline Car / jeep & 29.77 & 6 \\
\hline LCV & 15.35 & 4 \\
\hline Mini bus & 0.98 & 3.5 \\
\hline Trucks & 11.35 & 4 \\
\hline Govt. Bus & 4.56 & 3.5 \\
\hline Private Bus & 5.03 & 3.5 \\
\hline 3 Axle & 15.82 & 5 \\
\hline MAV & 14.4 & 5 \\
\hline
\end{tabular}

\section{Project Analysis}

In set up to the analysis, the Base Case (Without improvement) is compare With improvement i.e. strengthening and widening to six lanes with paved shoulder of flexible pavement is confirmed and a discount rate of 12 percent is specified. While running the project analysis, comparison is done against the Base Case, and reports are generated.

\section{SOCIO ECONOMIC BENEFITS}

The main of objective of the project is to improve the performance of the highway network. Some of expected socio-economic benefits of the project are being enumerated out as below:

- All the road users will benefit from the proposed improvement through increased comfort and reduced travel time.

- The society will benefit economically from the saving in vehicle operating costs due to enhanced speed and better geometric.

- The project also will open up the areas adjacent to the project road to increased economic activity.

- Local communities will have greater access to public infrastructure and increased mobility through enhanced transport facilities. 


\begin{tabular}{|c|c|c|c|c|c|c|c|c|c|}
\hline Vehicle Type & $\begin{array}{c}\text { Two- } \\
\text { Wheeler }\end{array}$ & Car / jeep & LCV & Mini bus & $\begin{array}{l}\text { Trucks } \\
\text { (2 Axle) }\end{array}$ & $\begin{array}{l}\text { Govt. } \\
\text { Bus }\end{array}$ & $\begin{array}{l}\text { Private } \\
\text { Bus }\end{array}$ & $\begin{array}{l}\text { Trucks } \\
\text { (3 Axle) }\end{array}$ & MAV \\
\hline No. of Wheels & 2 & 4 & 4 & 4 & 6 & 10 & 10 & 10 & 18 \\
\hline No. of Axle & 2 & 2 & 2 & 2 & 2 & 3 & 3 & 3 & $\geq 4$ to 6 \\
\hline Tyre Type & Radial & Radial & Radial & Radial & Radial & Radial & Radial & Radial & Radial \\
\hline $\begin{array}{c}\text { Service Life } \\
\text { (Years) }\end{array}$ & 10 & 10 & 10 & 8 & 10 & 10 & 10 & 10 & 10 \\
\hline $\begin{array}{c}\text { Annual Working } \\
\text { hours }\end{array}$ & 400 & 550 & 1300 & 850 & 1200 & 1750 & 1700 & 2050 & 1650 \\
\hline Annual Km & 10000 & 23000 & 30000 & 34000 & 40000 & 70000 & 72000 & 86000 & 81000 \\
\hline No. of Passengers & 1 & 3 & 0 & 20 & 0 & 40 & 40 & 0 & 0 \\
\hline $\begin{array}{c}\text { Private-Use } \\
\text { percentage }\end{array}$ & 100 & 75 & 50 & 25 & 0 & 0 & 25 & 0 & 0 \\
\hline $\begin{array}{l}\text { Work-Related } \\
\text { passenger trip }\end{array}$ & 0 & 25 & 50 & 75 & 100 & 100 & 75 & 100 & 100 \\
\hline ESAL factor & 0 & 0.000442 & 0.01 & 0.04 & 1.25 & 0.8 & 0.8 & 2.28 & 4.63 \\
\hline $\begin{array}{l}\text { The Operating } \\
\text { Weight (Ton) }\end{array}$ & 0.2 & 1.2 & 1.5 & 2.5 & 7.5 & 10 & 10 & 13 & 28 \\
\hline
\end{tabular}

\begin{tabular}{|c|c|c|c|c|c|c|c|c|c|}
\hline Name & Two-Wheeler & Car / jeep & LCV & Mini bus & Trucks & Govt. Bus & Private Bus & 3 Axle & MAV \\
\hline New Vehicle Cost & 50000 & 600000 & 400000 & 1000000 & 1200000 & 1800000 & 2200000 & 1500000 & 2000000 \\
\hline Tire Cost & 1500 & 5000 & 3500 & 10000 & 14000 & 20000 & 25000 & 18000 & 18000 \\
\hline Fuel (per liter) & 76 & 76 & 70 & 70 & 70 & 70 & 70 & 70 & 70 \\
\hline Lubricating Oil (per Liter) & 100 & 150 & 150 & 150 & 150 & 150 & 150 & 150 & 150 \\
\hline Crew Wages (per hr.) & 0 & 50 & 70 & 70 & 70 & 70 & 70 & 70 & 70 \\
\hline Annual Overhead & 1400 & 240000 & 120000 & 450000 & 360000 & 540000 & 660000 & 450000 & 600000 \\
\hline Cargo Holding (per hr.) & 0 & 0 & 8.42 & 0 & 26.31 & 0 & 0 & 58.34 & 58.34 \\
\hline Passenger Working (per hr.) & 75 & 218.7 & 0 & 145.8 & 0 & 121.48 & 130 & 0 & 0 \\
\hline $\begin{array}{l}\text { Passenger Non-working (per } \\
\text { hr.) }\end{array}$ & 20 & 49.35 & 0 & 32.9 & 0 & 27.4 & 32.5 & 0 & 0 \\
\hline
\end{tabular}

\section{RESULTS \& CONCLUSION}

This research paper deals with checking economic feasibility of highway project. As it is important to evaluate economic efficiency of road construction for decision maker to decide whether the proposed is credible of investment keeping in view of social benefits. The proposed project road strengthing and widening from 4 lane flexible pavement to six lanes of Mumbai-Pune section of NH-4. In order to find results both options of Without improvement and with improvement are compared with each other. However, economic analysis is also recommended that analysis period should not be too long, that it may find inaccurate results, so 20 -year analysis period is considered. The summary of Economic Internal Rate of Return (EIRR), as investment option for life cycle cost analysis is presented in Table VI and output summary of economic analysis is as shown in Fig. 2.

\section{TABLE VI RESULTS OF ECONOMIC ANALYSIS}

\begin{tabular}{|c|c|c|}
\hline Section Name & $\begin{array}{c}\text { Net Economic Benefit } \\
\text { (12\% Discounted Rate) }\end{array}$ & $\begin{array}{c}\text { Economic Internal } \\
\text { Rate of Return } \\
\text { (EIRR) }\end{array}$ \\
\hline $\begin{array}{c}\text { Mumbai Pune } \\
\text { Section of NH-4 }\end{array}$ & $23,834.62$ & $24.5 \%$ \\
\hline
\end{tabular}

As generated results shows Economic returns are acceptable for all components and calculated Economic Internal Rate of Return (EIRR) is more than $12 \%$ which is benchmark for rate comparison and substantially proves the project is economically viable for proposed improvement. Furthermore, the Highway Development \& Management (HDM-4) tool can forecast budget allocation over entire analysis period and plays important role in selection of optimum budget constraints. 


\section{H D M - 4 Economic Analysis Summary \\ HIGHWAY DEVELOPMENT \& MANAGEMENT Study Name: Widening of Mumbai - Pune Section of NH-4 \\ Run Date: 22-06-2020}

This report shows total economic benefits using the following

Currency: INR (millions).

Discount rate: $12.00 \%$.

Analysis Mode: Analysis-by-Project

Alternative: With Project vs Alternative: Base Case

\begin{tabular}{|c|c|c|c|c|c|c|c|c|c|}
\hline & \multicolumn{3}{|c|}{ Increase in Road Agency Costs } & \multirow{2}{*}{$\begin{array}{c}\text { Savings in } M \\
\text { VOC }\end{array}$} & \multirow{2}{*}{$\begin{array}{c}\text { Savings in MT } \\
\text { Travel } \\
\text { Time Costs }\end{array}$} & \multirow{2}{*}{$\begin{array}{l}\text { Savings in } \\
\text { NMT Travel } \\
\text { \& Operating } \\
\text { Costs }\end{array}$} & \multirow{2}{*}{$\begin{array}{l}\text { Reduction } \\
\text { in Accident } \\
\text { Costs }\end{array}$} & \multirow{2}{*}{$\begin{array}{l}\text { Net } \\
\text { Exogenou } \\
\text { s Benefits }\end{array}$} & \multirow{2}{*}{$\begin{array}{c}\text { Net } \\
\text { Economic } \\
\text { Benefits } \\
\text { (NPV) }\end{array}$} \\
\hline & Capital & Recurrent & Special & & & & & & \\
\hline Undiscounted & $72,150.00$ & $1,424.62$ & 0.00 & $113,871.80$ & $97,477.95$ & 0.00 & 0.00 & 0.00 & $137,775.15$ \\
\hline Discounted & $12,933.62$ & 782.18 & 0.00 & $30,668.23$ & $6,882.19$ & 0.00 & 0.00 & 0.00 & $23,834.62$ \\
\hline
\end{tabular}

Economic Internal Rate of Return $(E I R R)=24.5 \%($ No. of solutions $=1)$

Fig. 2. Output Summary of Economic Analysis

\section{ACKNOWLEDGMENT}

I take this opportunity to thank my research guide cum Head of the Program Prof. D. S. Patil and Head of the Department. Dr. P. D. Kumbhar for their valuable guidance and for providing all the necessary facilities, which were indispensable in the completion of this research work.

\section{REFERENCES}

[1] A. Pavan R. Vyas, "Project level analysis using development and management model (hdm-4): A case study," Conference paper, 2016.

[2] R. Tomek and S. Vit'asek, "Improvement of economic effectiveness of road highway projects," Procedia engineering, 2016, vol. 164, pp. 395-401.

[3] U. S. Yogesh, S. Jain, and T. Devesh, "Adaptation of hdm-4 tool for strategic analysis of urban roads network," Transportation Research Procedia, 2016, vol. 17, pp. 71-80.

[4] Mit Patel, Prof. N. D. Hajiani, "Economic Analysis of Transportation Project using HDM-4 Model," International Journal for Scientific Research \& Development, 2015, Vol. 3, Issue 02.

[5] Dr. Dipti Ranjan Mohapatra, "An Economic Analysis of Improvement of Road Infrastructure: A Case Study," European Academic Research, 2015, Vol. II, Issue 11.

[6] Jana Korytárováa, Vít Hromádkaa, "The Economic Evaluation of Megaprojects-Social and Economic Impacts," ProcediaSocial and Behavioral Sciences, 2014, vol. 119, 495-502.

[7] Ramaiah Bheenaveni, "Economic Assessment of Transportation Projects," International Journal of Multidisciplinary Research, 2013, vol. 3, Issue 3.
[8] R. B. Corotis, "Highway user travel time evaluation," Journal of Transportation Engineering, 2007, vol. 133, no. 12, pp. 663669.

[9] Henry Kerali, "Economic appraisal of road projects in countries with developing and transition economies," Transport Reviews, 2003, VOL. 23, NO. 3, 249-262

[10] Kerali, H. R., Robinson, R., and Paterson, W. D. O., 1998 "Role of the New HDM-4 in Highway Management." 4th Int. Conf. on Managing Pavements.

[11] Kerali, H. R., Odoki, J. B., Wightman, D. C., and Stannard, E. E., 1998. "Structure of the new Highway Development and Management Tools (HDM-4)." 4th Int. Conf. on Managing Pavements.

[12] Bennett, C. R., and Paterson, W. D. O., 2000. A Guide to Calibration and Adaptation, Highway Development and Management Series, Vol. 5, International Study of Highway Development and Management, World Roads Association, Paris.

[13] IRC: SP:30, "Manual on economic evaluation of highway project in India's in civil engineering 2009". 